\title{
Study of physico-chemical properties of Cassia tora Linn. leaves powder
}

K. J. Kamble and Shubhangi Dhage

Received : 08.08.2019; Revised : 26.08.2019; Accepted : 13.09 .2019

See end of the Paper for authors' affiliation

Correspondence to :

\section{K. J. Kamble}

Department of Agricultural Process Engineering, Dr. Annasaheb Shinde College of Agricultural Engineering and Technology (MPKV), Rahuri, Ahmednagar (M.S.) India Email : aaskk@rediffmail.com
- ABSTRACT : The study was undertaken to know the physico-chemical properties of Cassia tora powder obtained by drying at $60^{\circ} \mathrm{C}$ and packed $100,200,300$ gauges poly bags and stored for 60,120 and 180 days at room temperature. It was observed that Cassia tora leaves powder consists of m.c. $(\%)$, ash (\%), protein (\%), ascorbic acid (mg/100g), chlorophyll (mg/100g), fibre (\%), calcium $(\mathrm{g} / 100 \mathrm{~g})$ and fat $(\%)$ of was $4.07,8.15,12.51,19.6,39.68,27.42,3.52$ and 2.002 , respectively. This shows the rich profile of Cassia tora which could be an important component of diet in future. The colour values i.e. $\mathrm{L}^{*}, \mathrm{a}^{*}$ and $\mathrm{b}^{*}$ of powder were $58.608,-5.245$ and 21.132 , respectively showing acceptable colour values as leafy vegetable. It was also observed that there was no significant effect of packaging on moisture content of the powder upto 180 days but it showed little effect on protein and ascorbic acid content. Interaction of treatments showed non-significant effect on the moisture and protein content but showed little effect on ascorbic acid content. All the treatments of packaging showed non-significant effect of storage on fibre and calcium content where as little effect on fat content of the powder. Powder stored for a period of 60,120 and 180 days showed little effect on fibre, calcium and fat content and treatment interaction also showed non-significant effect on the constituents.

- KEY WORDS : Physico-chemical properties, Leaves, Powder

- HOW TO CITE THIS PAPER : Kamble, K. J. and Dhage, Shubhangi (2019). Study of physicochemical properties of Cassia tora Linn. leaves powder. Internat. J. Agric. Engg., 12(2) : 235-242, DOI: 10.15740/HAS/IJAE/12.2/235-242. Copyright@2019: Hind Agri-Horticultural Society. 